\title{
QUALITY
}

Volume 7, Nomor 2, 2019: 100-113

\section{SENI BACA AL-QURAN: METODE EFEKTIF DALAM PEMBELAJARAN AL-QURAN HADITS}

\author{
Maskur \\ Sekolah Tinggi Ilmu Agama Wali Sembilan, Semarang, Indonesia \\ maskur2106128401@gmail.com
}

\begin{abstract}
Abstrak
Membaca merupakan bagian dari proses pembelajaran. Dengan membaca akan mendukung kegiatan pembelajaran yang dilakukan baik di kelas maupun di pondok pesantren. Pembelajaran dalam membaca Al-quran pada dasarnya harus memperhatikan prinsip-prinsip utama yang perlu dipahami oleh setiap pengajar. Hal ini karena pembelajaran membaca Al-quran tentunya berbeda dengan pembelajaran membaca buku, novel maupun membaca yang lain. Tujuan penelitian ini adalah untuk melihat implementasi pembelajaran seni membaca Al-quran dalam pembelajaran Alquran Hadits. Dengan demikian akan dapat dilihat secara jelas bagaimana penerapan seni membaca Al-quran dilihat dari keefektifannya dalam pembelajaran Al-Quran Hadits.
\end{abstract}

Kata Kunci : metode efektif, seni baca Al-Qur'an, Al-Quran Hadits

\begin{abstract}
Abstrack
Reading is part of the learning process. Reading will support learning activities carried out both in the classroom and in the Islamic boarding school. Learning in reading the Koran basically must pay attention to the main principles that need to be understood by every teacher. This is because learning to read the Qur'an is certainly different from learning to read books, novels and other reading. The purpose of this study is to look at the implementation of the learning of the art of reading the Qur'an in the learning of AlQur'an Hadith. Thus it will be seen clearly how the application of the art of reading the Koran is seen from its effectiveness in learning Al-Quran Hadith.
\end{abstract}

Keywords: effective method, art of reading Al-Qur'an, Al-Quran Hadith 


\section{A. Pendahuluan}

Pendidikan merupakan proses pengubahan proses dan tata laku seseorang atau kelompok orang dalam usaha mendewasakan manusia melaluiupaya pengajaran dan pelatihan (Damsar, 2011: 8). Pendidikan tersebut dapat dilaksanakan di semua lini kehidupan, baik dari lingkup keluarga, sekolah, maupun masyarakat. Proses pengubahan tata laku seseorang tentunya dapat dilakukan melalui berbagai proses belajar, diantara melalui kegiatan membaca, menulis maupun berbicara. Dalam konteks yang sebenarnya di dalam Al-quran telah disebutkan bahwa membaca adalah perintah pertama yang diberikan Allah kepada manusia yang sudah tercantum dalam surat Al-Alaq ayat 1-5. Ayat dalam surat tersebut secara jelas memberikan pemahaman tentang pentingnya membaca. Hal ini karena dengan kegiatan membaca, akan mampu merangsang keingintahuan seseorang terhadap halhal yang baru.

Al-quran sebagai kitab yang diturunkan Allah kepada manusia merupakan kitab yang wajib dibaca dan diamalkan. Membaca Al-quran bahkan dapat dikatakan sebagai salah satu bentuk Ibadah yang dianjurkan. Al-quran sebagai sumber pengetahuan tentunya akan memberikan banyak pemahaman bagi manusia yang mau membaca, menelaah dan meneliti kandungan isi Al-quran. Hal ini karena Alquran merupakan kalam Illahi yang diturunkan kepada Nabi Muhammad Saw tertulis di dalam mushaf berdasarkan sumber-sumber mutawatir danbersifat pasti kebenaranya, dan yang dibaca oleh umat Islam dalam rangkaibadah (Al-Qathan, 2011:14).

Membaca Al-quran dapat dianggap sebagai bentuk ibadah jika dalam membaca Al-quran tersebut sesuai dengan kaidah atau tajwid yang benar. Membaca merupakan kunci pengetahuan,tanpa membaca pengetahuan manusia tentu tidak akan berkembang dengan baik. Membacaadalah suatu proses yang dilakukan serta dipergunakan oleh pembaca untukmemperoleh pesan, yang hendak disampaikan oleh penulis melalui media bahasa (Tarigan, 2008: 7). Memotivasi membaca Alquran tentunya bukanlah hal yang mudah, sehingga diperlukan cara untuk bisa memotivasi siswa atau santri dalam membaca, salah satunya dengan seni membaca Al-quran. Seni merupakan salah satu hal yang dapat memotivasi seseorang untuk 
melakukan sesuatu, salah satunya juga akan memotivasi dalam membaca Al-quran. Seni dalam membaca Al-quran atau An-Naghom fil Qur`an merupakan cara untuk memperindah suara pada tilawatil Qur`an, dengan adanya seni dalam membaca Alquran tentunya akan mempermudah dalam proses pembelajaran, terutama dalam pembelajaran Al-quran hadits.

Mengajarkan seni membaca Al-quran pada dasarnya tidak hanya mengajarkan keindahan dalam melantunkan ayat Al-quran akan tetapi juga mengutamakan tajwid serta pemahaman tentang arti dari ayat-ayat yang dilantunkan. Hal tersebut tentunya akan memberikan manfaat bagi siswa atau santri dalam memaknai kandungan ayat Al-quran yang dipelajarinya. Dengan memahami isi maupun kandungan ayat Alquran yang dipelajarai tentunya diharapkan akan dapat memotivasi para santri untuk mau membaca Al-quran dengan penuh kesadaran. Hal tersebut juga karena kandungan Al-quran merupakan kitab yang terbaik bila dibandingkan dengan kitab karangan manusia manapun (Annuri, 2010:8).

Berdasarkan hasil observasi awal di Pondok Pesantren Syaroful Millah Semarang, dapat dilihat para santri telah memiliki kemampuan membaca Al-quran dengan baik, hanya saja masih ada beberapa santri yang kurang bersemangat dalam membaca Al-Quran terutama dengan standar membaca dengan lagu yang biasa. Dengan melihat latar belakang tersebut, peneliti tertarik untuk melakukan penelitian tentang seni membaca Al-quran terutama sebagai metode yang efektif dalam pembelajaran Al-quran Hadits.

Tujuan penelitian ini adalah untuk melihat implementasi pembelajaran seni membaca Al-quran dalam pembelajaran Al-quran Hadits. Dengan demikian akan dapat dilihat secara jelas bagaimana penerapan seni membaca Al-quran dilihat dari keefektifannya dalam pembelajaran Al-Quran Hadits.

Metode dalam penelitian ini adalah penelitian kualitatif yang berupaya untuk mendiskripsikan implementasi pembelajaran seni membaca Al-quran. Metode penelitian kualitatif merupakan metode penelitian yang digunakan untuk meneliti obyek yang alamiah, (sebagailawannya adalah eksperimen) dimana peneliti adalah sebagai instrumenkunci, teknik pengumpulan data dilakukan secara triangulasi (gabungan), analisis data bersifat induktif, dan hasil penelitian kualitatif lebih menekankanmakna dari pada generalisasi (Sugiyono, 2016: 9). Dalam penelitian 
kualitatif data masih bersifatsementara dan akan berkembang atau berubah saat peneliti berada dilapangan. Hal ini karena permasalahan dalam penelitian kualitatif dapat berkembang sesuai apa yang ada di lapangan sehingga memungkinkan data yang diperoleh juga akan berubah sesuai dengan apa yang ada di lapangan.

Penelitian kualitatif dapat terjadi kemungkinan terhadap masalah yang dibawa oleh peneliti karena permasalahan yang dibawa peneliti ke lapangan masih bersifat sementara, maka teori yang digunakan dalam penyusunan proposal penelitian kualitatif juga masih bersifat sementara sehingga dapat melihat masalah lebih luas, masalah berkembang dan masalah akan berubah total saatdi lapangan.Dengan mendeskripsikan secara jelas terkait implementasi pembelajaran seni membaca Alquran, maka akan dapat dilihat dari perencanaan, pelaksanaan maupun evaluasi dalam proses pembelajaran.

Penelitian ini juga berpijak dari penelitian sebelumnya yakni dari penelitian Satturi yang berjudul Implementasi Gemar Mengaji dalam Pembinaan Baca Tulis Al-Quran Perspektif Pendidikan Islam Marioriwawo Kabupaten Soppeng tahun 2018. Penelitian Satturi menghasilkan temuan diantaranya: 1) Gambaran implementasigemar mengaji di Kecamatan Marioriwawo Kabupaten Soppeng sangat lancar dan guru-guru mengaji di Kecamatan Marioriwawo Kabupaten Soppeng telah berperan aktif dalam mengajarkan Al-qur'an dan mengembangkan beberapa metode termasuk metode latihan gemar mengaji meliputi peningkatan mutu dan memberikan bimbingan secara efektif sehingga peserta didik dapat berkembang secara optimal sesuai dengan potensi yang dimiliki, dan menciptakan lingkungan di Kecamatan Marioriwawo Kabupaten Soppeng yang religius. 2) kemampuan membaca Al-quran peserta didik pada pelaksanaan gemar mengaji di Kecamatan Marioriwawo Kabupaten Soppeng yang berisikan kegiatan-kegiatan bersifat operasional yaitu ; tindakan dan pembelajaran yang sistematis, target yang akan dicapai atau diinginioleh pemerintah dan masyarakat, dan kegiatan mengaji yang digambarkan untukmenanamkan nilai-nilai Qur'ani untuk mencapai tujuan.3) Kendala-kendala dan solusi yang dihadapi dalam implementasi pembelajaran Alqur'an pada gemar mengaji di Kecamatan Marioriwawo Kabupaten Soppeng dalam upaya pembinaan baca tulis Al-qur'an yaitu; pertama sikap acuh orang tua terhadap anaknya dalam memotivasi membaca dan menulis Al-quran serta pengaruh 
teknologi (HP) sangat cepat dan keikutsertaan orang tua dalam pembinan baca tulis Al-quran sangatminim. Adapun solusi dalam mengatasi kendala-kendala yang dihadapi yaitu; sikaporang tua dalam memberikan motivasi, pengaruh teknologi HP dibatasi, melakukanbimbingan secara intensif, memberikan tugas tambahan peserta didik, sertameningkatkan insentif guru mengaji dan meningkatkan pelatihan bagi guru-gurumengaji.

Telaah pustaka yang kedua adalah penelitian dari Anis Nur Wahyuni yang berjudul Implementasi Pembelajaran Baca Tulis Al-quran dengan Metode Al-Tartil di MI Persiapan Negeri Miftahul Huda Turen Tahun 2018. Dari penelitian tersebut ditemukan beberapa hal yaitu: 1) perencanaan baca tulis Al-quran dengan metode Al-tartil berpedoman pada RPP yang sudah dirancang oleh pusat koordinator AlTartil, guru hanya tinggal menyesuaikan dengan RPP dan mengatur kondisi siswa dalam kelas, sedangkan persiapan yang diperlukan sendiri yaitu materi penunjang hafalan surat pendek, doa sehari-hari dan menulis arab guna meningkatkan kualitas kemampuan siswa. 2) pelaksanaan pembelajaran baca tulis Al-quran dengan metode al-tartil dimulai dengan melafalkan doa sehari-hari atau surat-surat pendek bersamasama kemudian masuk materi guru membacakan serta menjelaskan sedangkan siswa menyimak pada buku jilid, setelah itu siswa membaca bersama-sama beberapa kali setelah itu dilakukan dengan menulis. 3) Evaluasi pembelajaran baca tulis Al-quran dengan metode al-tartil, penilaian harian dilaksanakan setiap akhir pertemuan pebelajaran siswa dites maju satu persatu ke depan guru. Penilaian kenaikan jilid dilaksanakan oleh pihak madrasah dan terdapat tim guru untuk melaksanakan tes. Penilaian kenaikan tingkat dari jilid ke marhalah dilaksanakan oleh kantor pusat koordinator altartil.

Berdasarkan telaah pustaka dari penelitian-penelitian terdahulu dapat diketahui bahwa penelitian yang peneliti lakukan berbeda dengan penelitian terdahulu. Hal ini karena penelitian Satturi lebih menekankan pada implementasi gemar mengaji dalam pembinaan baca tulis Al-quran dalam perspektif Pendidikan Islam, sehingga temuan yang dihasilkan lebih mengarah pada implementasi gerakan mengaji dan kemampuan membaca Al-quran peserta didik serta kendala-kendala yang dihadapi dan solusi yang dihadapi dalam implementasi pembelajaran Al-qur'an pada gemar mengaji di lokasi penelitian dalam upaya pembinaan baca tulis Al- 
quran. Penelitian yang kedua lebih mengarah pada implementasi pembelajaran baca tulis Al-quran dengan metode Al-tartil di lokasi penelitian baik dari perencanaan, pelaksanaan dan evaluasi yang dilakukan.

Melihat beberapa penelitian terdahulu dapat dilihat nilai baru dari penelitian ini adalah pada penggunaan metode seni baca Al-quran sebagai metode efektif dalam pembelajaran Al-quran Hadits. Dengan demikian penelitian ini berbeda dengan penelitian-penelitian sebelumnya.

\section{B. Pembahasan}

Membaca Al-quran merupakan suatu kewajiban umat muslim. Hal ini karena dengan membaca tidak hanya memberikan pengetahuan bagi yang membacanya, akan tetapi akan menambah keimanan bagi orang yang membaca Al-quran tersebut. Membaca merupakan bagian dari proses pembelajaran. Dengan membaca akan mendukung kegiatan pembelajaran yang dilakukan baik di kelas maupun di pondok pesantren. Pembelajaran dalam membaca Al-quran pada dasarnya harus memperhatikan prinsip-prinsip utama yang perlu dipahami oleh setiap pengajar. Hal ini karena pembelajaran membaca Al-quran tentunya berbeda dengan pembelajaran membaca buku, novel maupun membaca yang lain. Adapun prinsip-prinsip dalam membaca Al-quran adalah sebagai berikut:

\section{Membaca dengan tahqiq}

Tahqiq adalah membaca dengan memberikan hak-hak setiap hurufsecara tegas, jelas, teliti, seperti memanjangkan mad, menegaskanhamzah, menyempurnakan harakat, melepaskan huruf secara tartil,pelan-pelan memperhatikan panjang pendek, waqaf dan ibtida' tanpamelepas huruf. Dalam penerapannya metode tahqiq ini tampak memenggal-menggal dan memutus-mutus dalam membaca huruf-hurufdan kalimat-kalimat Al-quran (Syarifudin, 2005: 79).

\section{Membaca dengan tartil}

Tartil artinya membaca Al-quran dengan perlahan-perlahan tidakterburu-buru dengan bacaan yang baik dan benar sesuai dengan makhrajdan sifat-sifatnya sebagaimana yang dijelaskan dalam ilmu tajwid. Makharijul huruf yaitu membaca huruf-huruf hijaiyah sesuai dengantempat keluarnya seperti tenggorokan, di tengah lidah, antara dua bibirdan lain-lain. Tartil 
lebihmenekankan aspek memahami dan merenungi kandungan ayat-ayat Alquran (Khon, 2008: 44).

\section{Membaca dengan Tadwir}

Tadwir adalah membaca Al-qur`an dengan memanjangkan mad,hanya tidak sampai penuh.

\section{Membaca dengan Hadr}

Hadr adalah membaca Al-Qur`an dengan cara cepat, ringan danpendek, namun tetap dengan menegakkan awal dan akhir kalimat serta meluruskannya. Suara mendengung tidak sampai hilang, meski cara membacanya cepat dan ringan.

Pembelajaran membaca $\mathrm{Al}$-quran selain harus memahami prinsip-prinsip tersebut, hal yang penting adalah memahami garis-garis besar dalam sistem pembelajaran Al-quran (Darajat, 2010:91), yaitu sebagai berikut:

a) Pengenalan huruf hijaiyah

b) Cara membunyikan masing-masing huruf hijaiyah dan sifat-sifat huruf itu yang dipelajarai dalam ilmu makhraj

c) Bentuk dan fungsi tanda baca, seperti syakal, syaddah, dan mad bacaan panjang

d) Bentuk dan fungsi tanda baca waqaf.

Dengan memahami prinsip-prinsip dalam pembelajaran membaca Al-quran maupun garis-garis besar dalam pembelajaran Al-quran maka akan lebih mudah dalam menggunakan seni lagu dalam melantunkan ayat-ayat Al-quran. Pembelajaran seni membaca Al-quran pada dasarnya tetap mengutamakan pembelajaran tajwid, fasohah tentang kefasihan membaca, memaknai isi ayat Al-quran dan menghayati ayat yang dibaca (maqro'), serta berkaitan dengan lagu dan rumus tilawah. Adapun Rumus lagu atau Tausyih yang diajarkan adalah bayyati, shoba, nahawand, hijaz, rost, sika dan jiharka. Pengenalan lagu-lagu tersebut diajarkan secara bertahap dan perlahan-lahan sampai semua santri dapat menguasai semua rumus tersebut.

Berdasarkan hasil penelitian dapat diketahui bahwa implementasi seni membaca Al-quran di pondok pesantren Syaroful Millah dapat dilihat dari perencanaan, pelaksanaan dan evaluasi dari proses pembelajarannya. Adapun dalam setiap fase tersebut dapat didiskripsikan sebagai berikut: 


\section{Tahap Perencanaan}

Perencanaan merupakan tahap awal sebelum dilaksanakan proses pembelajaran. Dalam tahap ini guru mempersiapkan perangkat pembelajaran, terutama mempersiapkan materi yang akan diajarkan, yakni memilih ayat Alquran yang akan diajarkan kepada para santri. Setelah memilih ayat-ayat Alquran yang akan diajarkan, guru juga mempersiapkan peralatan yang akan digunakan dalam pembelajaran misalnya tape recorder, televisi atau vcd yang akan memperjelas proses pembelajaran. Media-media tersebut digunakan untuk memperjelas dalam memberikan contoh kepada para santri, sehingga pembelajaran yang dilakukan bersifat lebih konkrit karena selain dicontohkan langsung oleh guru juga diberi contoh beberapa lantunan ayat Al-quran dari berbagai versi.

Pada tahap perencanaan guru juga merencanakan surat-surat yang akan diajarkan kepada para santri. Pemilihan surat-surat diutamakan yang dapat memberikan pemahaman tentang ibadah, menjaga kebaikan dan lain sebagainya. Adapun surat-surat yang akan dipilih adalah surat Al-Isro' ayat 12, surat Alfatihah, Surat Attin, surat Al Baqoroh ayat 183 dan surat At-Taubah ayat 71. Pembelajaran dialokasikan selama 4 kali pertemuan, dimana setiap kali pertemuan waktu pembelajaran adalah selama $2 \times 45$ menit.

Pembelajaran direncanakan dilaksanakan secara individu maupun kelompok agar dalam proses pembelajaran santri yang sudah bisa dapat membantu temannya yang belum bisa serta santri yang belum bisa dapat termotivasi untuk bisa membaca Al-quran dengan metode seni membaca Alquran.

2. Tahap pelaksanaan

Pelaksanaan pembelajaran seni membaca Al-quran tentunya dilaksanakan sesuai dengan perencanaan yang telah dilakukan sebelumnya. Mengajarkan seni membaca Al-quran selalu berkaitan dengan lagu dan rumus tilawah atau disebut dengan tausyih. Dalam pelaksanaan pembelajaran hal yang paling diutamakan adalah bacaan para santri. Tajwid maupun kefasihan adalah hal yang paling diutamakan dalam membaca Al-quran, sehingga 
mempelajari lagu juga dibarengi dengan mempelajari tajwid setiap ayat yang dibaca maupun kefasihan dari bacaan yang dilantunkan para santri.

Berdasarkan hasil penelitian di Pondok pesantren Syaroful Millah yang terletak di daerah Semarang dapat dilihat dengan menggunakan metode seni baca Al-quran, dari 25 santri yang ada 20 santri dapat dilihat antusias dalam proses pembelajaran. Antusias tersebut nampak dalam kefasihan maupun tajwid bacaan dari ayat-ayat Al-quran yang dibaca maupun ketepatan lagu dari setiap rumus yang telah diajarkan oleh guru.

Pada tahap pelaksanaan dapat diketahui bahwa dalam pembelajaran seni membaca Al-quran, hal yang selalu ditekankan guru adalah mengutamakan pembelajaran tajwid, fasohah tentang kefasihan membaca, memaknai isi ayat Al-quran dan menghayati ayat yang dibaca (maqro'), serta berkaitan dengan lagu dan rumus tilawah. Adapun Rumus lagu atau Tausyih yang diajarkan adalah bayyati, shoba, nahawand, hijaz, rost, sika dan jiharka. Pengenalan lagu-lagu tersebut diajarkan secara bertahap dan perlahan-lahan sampai semua santri dapat menguasai semua rumus tersebut.

Dalam implementasi metode seni membaca Al-quran semua rumus tersebut diajarkan untuk melantunkan satu atau dua ayat Al-quran yang diajarkan. Hal ini agar semua santri dapat menguasai semua rumus lagu dengan benar dan lancar. Adapun dalam pelaksanaan pembelajaran ayat-ayat Al-quran yang dipilih adalah:

a. Surat Al-Isro' ayat 1-2

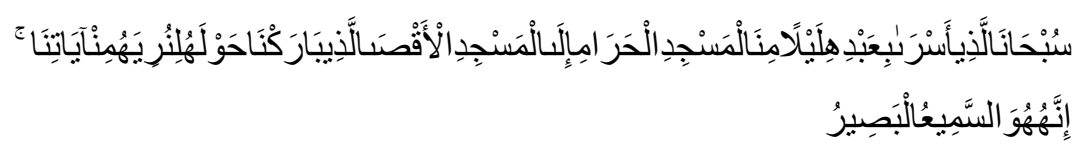

Artinya: Maha Suci Allah, yang telah memperjalankan hamba-Nya pada suatu malam dari Al Masjidil Haram ke Al Masjidil Aqsha yang telah Kami berkahi sekelilingnya agar Kami perlihatkan kepadanya sebagian dari tanda-tanda (kebesaran) Kami. Sesungguhnya Dia adalah Maha Mendengar lagi Maha Mengetahui. 
Surat Al-Isro' ayat 1 dan 2 tersebut berisi tentang peristiwa isro' mi'raj yang merupakan salah satu tanda kebesaran Allah. Peristiwa isra' mi'raj tentunya dapat mempertebal keimanan dan ketakwaan bagi hamba yang beriman.

b. Surat Alfatihah

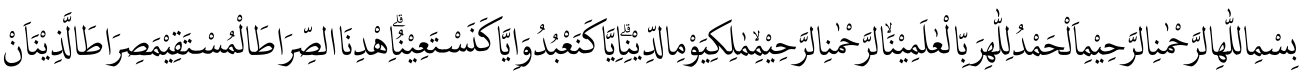

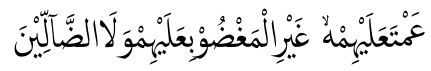

Artinya: Dengan nama Allah Yang Maha Pengasih, Maha Penyayang. Segala puji bagi Allah, Tuhan seluruh alam,Yang Maha Pengasih, Maha Penyayang, Pemilik hari pembalasan. Hanya kepada Engkaulah kami menyembah dan hanya kepada Engkaulah kami mohon pertolongan. Tunjukilah kami jalan yang lurus,(yaitu) jalan orang-orang yang telah Engkau beri nikmat kepadanya; bukan (jalan) mereka yang dimurkai, dan bukan (pula jalan) mereka yang sesat.

Surat Alfatihah tersebut berisi tentang ketahui dan serta Allah tempat segala hal yang manusia pinta dan Allah merupakan tempat untuk meminta petunjuk yang benar.

c. Surat Attin

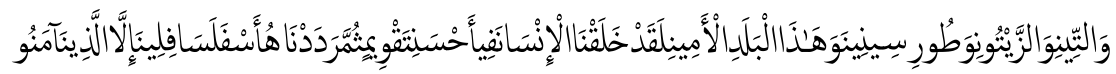

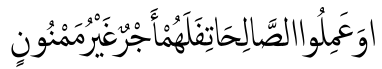

Artinya: Demi (buah) Tin dan (buah) Zaitun,dan demi bukit Sinai,an demi kota (Mekah) ini yang aman,sesungguhnya Kami telah menciptakan manusia dalam bentuk yang sebaik-baiknya. Kemudian Kami kembalikan dia ke tempat yang serendah-rendahnya (neraka), kecuali orang-orang yang beriman dan mengerjakan amal saleh; maka bagi mereka pahala yang tiada putus-putusnya.

Surat Attin dipilih sebagai salah satu surat yang dipelajari dalam pembelajaran dengan menggunakan metode seni membaca Al-quran karena kandungan surat tersebut mengajarkan kepada manusia untuk selalu memahami bahwa manusia merupakan makhluk yang paling sempurna 
namun akan dikembalikan ke tempat yang serendah-rendahnya kecuali orang-orang yang beriman dan mengerjakan amal saleh.

d. Surat Al Baqoroh ayat 183

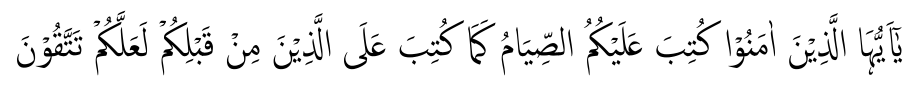

Artinya: Hai orang-orang yang beriman, diwajibkan atas kamu berpuasa sebagaimana diwajibkan atas orang-orang sebelum kamu agar kamu bertakwa.

Surat Al-baqoroh ayat 183 tersebut berisi tentang kewajiban berpuasa bagi orang-orang yang beriman. Dengan memahami bahwa puasa merupakan kewajiban bagi orang yang beriman, maka manusia senantiasa diharapkan menjadi manusia yang beriman dan dapat menjalankan ibadah puasa.

e. Surat At-Taubah ayat 71 .

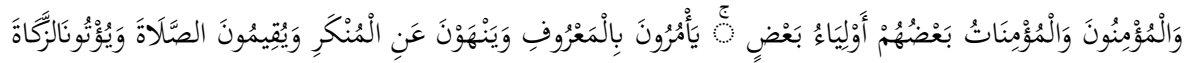

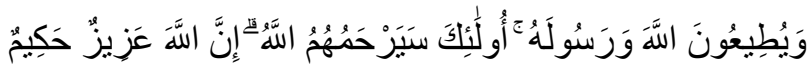

Artinya: 'Dan orang-orang yang beriman, lelaki dan perempuan, sebahagian mereka (adalah) menjadi penolong bagi sebahagian yang lain. Mereka menyuruh (mengerjakan) yang ma'ruf, mencegah dari yang munkar, mendirikan shalat, menunaikan zakat dan mereka taat pada Allah dan RasulNya. Mereka itu akan diberi rahmat oleh Allah; sesungguhnya Allah Maha Perkasa lagi Maha Bijaksana’’.

Surat At-taubah ayat 71 berisi mengandung makna bahwa sesama mukmin adalah menjadi pelindung mukmin yang lainnya. Pelindung dapat diartikan untuk mengajak mengerjakan hal yang baik dan mencegah perbuatan yang mungkar, mendirikan shalat, menunaikan zakat serta himbauan untuk taat pada Allah dan Rasul-Nya. Bagi orang-orang yang taat kepada Allah tentunya akan senantiasa diberikan rahmat karena Allah merupakan Maha Perkasa lagi Maha Bijaksana.

Pembelajaran seni membaca Al-quran dilaksanakan dengan diawali penjelasan dan pemberian contoh yang dilakukan oleh guru, kemudian 
secara bersama-sama dilakukan dengan para santri. Pembelajaran juga dilakukan dengan memberikan tugas secara individu untuk menirukan satu persatu ayat Al-quran yang telah dicontohkan oleh guru.

Keberhasilan pembelajaran tentunya tidak hanya dalam lagu yang dibawakan para santri dalam melantunkan ayat Al-quran tetapi juga mulai dari tajwid, kefasihan hingga kemampuan santri dalam memahami makna atau kandungan dari setiap ayat-ayat $\mathrm{Al}$-quran yang diajarkan.

3. Tahap evaluasi

Pada tahap evaluasi dapat dilihat dari beberapa hal yang menjadi penilaian dalam seni membaca Al-quran, yaitu dari tajwid, fasohah tentang kefasihan membaca, memaknai isi ayat Al-quran dan menghayati ayat yang dibaca (maqro'), serta berkaitan dengan lagu dan rumus tilawah. Berdasarkan hasil evaluasi yang dilakukan dapat dilihat dari 25 santri yang melaksanakan proses pembelajaran 21 santri mampu melaksanakan proses pembelajaran dengan sesuai.

Indikator untuk menilai kemampuan para santri dalam pembelajaran Alquran hadits menggunakan metode seni membaca Al-quran adalah tajwid, fasohah, kemampuan memahami isi ayat Al-quran yang dibaca serta kemampuan dalam melantunkan lagu dan rumus tilawah yang telah diajarkan. Berdasarkan hasil evaluasi dapat dilihat bahwa 10 santri mampu mencapai empat indikator tersebut dengan benar, 8 santri mampu mencapai 3 indikator keberhasilan pembelajaran serta sisanya yakni 7 santri mampu mencapai 2 indikator keberhasilan pembelajaran. Dengan melihat hasil dari proses evaluasi tersebut dapat diketahui bahwa metode seni membaca Al-quran merupakan salah satu metode yang cukup efektif dalam pembelajaran Al-quran hadits dan dapat digunakan sebagai referensi dalam pembelajaran membaca Al-quran. 


\section{Simpulan}

Berdasarkan hasil penelitian dapat disimpulkan bahwa implementasi seni membaca Al-quran dilaksanakan dari tahap perencanaan, pelaksanaan dan evaluasi. Tahap perencanaan guru mempersiapkan perangkat pembelajaran, terutama mempersiapkan materi yang akan diajarkan, yakni memilih ayat Al-quran yang akan diajarkan kepada para santri, memilih media dan peralatan yang akan digunakan dalam pembelajaran. Pada tahap pelaksanaan dapat diketahui bahwa dalam pembelajaran seni membaca Al-quran, hal yang selalu ditekankan guru adalah mengutamakan pembelajaran tajwid, fasohah tentang kefasihan membaca, memaknai isi ayat Al-quran dan menghayati ayat yang dibaca (maqro'), serta berkaitan dengan lagu dan rumus tilawah. Adapun Rumus lagu atau Tausyih yang diajarkan adalah bayyati, shoba, nahawand, hijaz, rost, sika dan jiharka. Pengenalan lagu-lagu tersebut diajarkan secara bertahap dan perlahan-lahan sampai semua santri dapat menguasai semua rumus tersebut. Tahap evaluasi dapat terlihat bahwa evaluasi dapat dilihat bahwa 10 santri mampu mencapai empat indikator tersebut dengan benar, 8 santri mampu mencapai 3 indikator keberhasilan pembelajaran serta sisanya yakni 7 santri mampu mencapai 2 indikator keberhasilan pembelajaran. 
Maskur

\section{Daftar Pustaka}

Al-Qathan, Manna. 2011. Pengantar Studi Ilmu al-Qur'an, Terjemahan dari Mabaahits fi Ulumil Qur'an oleh Aunur Rafiq El-Mazni. Jakarta:Pustaka Al-Kautsar.

Annuri, Ahmad. 2010. Panduan Tahsin Tilawah al-Qur'an \& Ilmu Tajwid. Jakarta:Pustaka Al-Kautsar.

Damsar. 2011. Pengantar Sosiologi Pendidikan. Jakarta: Kencana Prenada Media Group.

Darajat, Zakiyah et.al. 2010. Metodik Khusus Pendidikan Agama Islam, Jakarta: Bumi Aksara.

Kementerian Agama RI. 2012. Al-Qur'an dan Terjemahnya. Jakarta: PT Sinergi Pustaka Indonesia.

Khon, Abdul Majid. Praktikum Qiraat Keanehan Bacaan Al-Qur`An Qiraat Ashim Dari Hafash. Jakarta: Sinar grafika offset.

Sugiyono. 2016. Metode Penelitian Kuantitatif, Kualitatif dan R\&D. Bandung : PT Alfabet.

Syarifuddin, Ahmad. 2005. Mendidik Anak, Membaca, Menulis dan Mencintai alQur'an.Jakarta: Gema Insani.

Tarigan, Henry Guntur. 2008. Membaca Sebagai Suatu Keterampilan Berbahasa. Bandung: Angkasa. 